\title{
The Effect of Organizational Justice and Organizational Climate on Organizational Commitments (Job Satisfaction as a Mediation Variable in PT. Andalan Mitra Prestasi Padang)
}

\author{
Aris Setia Budi ${ }^{1}$, Yasri ${ }^{2}$ \\ 1Universitas Negeri Padang, Padang, Indonesia, $\square$ Arissetia1994.as@gmail.com \\ ${ }^{2}$ Universitas Negeri Padang, Padang, Indonesia, $\square$ yasrifeunp@gmail.com
}

\begin{abstract}
The effect of organizational justice and organizational climate on organizational commitment with job satisfaction as a mediation variable, PT. Andalan Mitra Prestasi Padang. The purpose of this study was to analyze: 1) Organizational justice influence on organizational commitment, 2) effect organizational climate on organizational commitment, 3) effect of organizational justice on job satisfaction, 4) effect of organizational climate on job satisfaction, 5) effect of job satisfaction on commitment organization. The population of this research is PT. Andalan Mitra Prestasi Padang amounting 70 people, sampling techniques of systematic random sampling, with a sample of 60 people. Data collection was through questionnaires. The data analysis technique in this study uses Structural Equation Model (SEM)-Pertial Least Square (PLS). The results of this research are: 1) organizational justice gives influential positive and significant to the organizational commitment of PT. Andalan Mitra Prestasi Padang. 2) Organizational justice has a positive and significant effect on job satisfaction of PT. Andalan Mitra Prestasi Padang. 3) Organizational climate gives a positive and significant effect on PT. Andalan Mitra Prestasi Padang positive and significant commitment. 4) Organizational climate gives a positive and significant effect on job satisfaction of PT. Andalan Mitra Prestasi Padang employees. 5) Job satisfaction provides a negative and not significant effect on PT. Andalan Mitra Prestasi Padang organizational commitment.
\end{abstract}

Keyword: organizational justice, organizational climate, job satisfaction, and organizational commitment.

\section{Introduction}

Every organization has human resources which are the most important assets for the company. Employees are active actors and have enthusiasm in every activity of the organization, doing work efficiently with global competition, advancing technology, and changing the nature of work, organizations are required to be able to retain employees so that the goals they want are not hampers (Dessler, 2015). According to (Lotfi and Pour, 2013), human resources are the most important part of each organization and if this part is more qualified, the probability of success, survival and increasing organizational success. One of the company's strategies to maintain its employees is by continously increasing employee commitment to the organization.

According to (Lotfi and Pour, 2013) loyal employees, satisfied consistent with the organizational goals, tend to be maintained by the organization, so that it becomes an important factor in the effectiveness of achieving organizational goals. Employees with high commitment in the organization have a higher performance and a lower level of absence, delay and have an organizational image displayed accordingly.

According to (Robbins and Judge, 2008) organizational commitment is a condition in which an employee sided with a particular organization and its purpose and desire to maintain membership in the organization. Organizational commitment reflects a form of identification, loyalty and involvement expressed by employees towards the organization (Gibson,2009).

PT. Andalan Mitra Prestasi is a company that provides and places labor services in the county and abroad. Continues to grow and even as 20 branch offices spread across. Various provinces in Indonesia. The purpose of this company was established to become one of the services companies in 
the field of employment that can help the government create jobs to improve the standard of living of small communities. The purpose of PT. Andalan Mitra Prestasi can be achieved if the employee is highly committed to the company.

The phenomena that occur at PT. Andalan Mitra Prestasi according to the information the author gets through interviews with HRD PT. Andalan Mitra Prestasi that the lack of employee loyalty to the organization is shown by many employee who choose to resign from the company for various reasons such as being accepted for work an other companies, moving residence or domicile and getting married. This phenomenon is also proven by the following table:

Table 1 Employees PT. Andalan Mitra Prestasi Padang Resign 2013-2017

\begin{tabular}{llllll}
\hline Number & Year & Operational & $\begin{array}{c}\text { Business and } \\
\text { HRD }\end{array}$ & $\begin{array}{c}\text { Financial and } \\
\text { Accountant }\end{array}$ & Total \\
\hline 1. & 2013 & 2 persons & 4 persons & 3 persons & 9 persons \\
\hline 2. & 2014 & 4 persons & 5 persons & 2 persons & 11 persons \\
\hline 3. & 2015 & 3 persons & 3 persons & 2 persons & 8 persons \\
\hline 4. & 2016 & 4 persons & 6 persons & 3 persons & 13 persons \\
\hline 5. & 2017 & 5 persons & 6 persons & 2 persons & 13 persons \\
\hline
\end{tabular}

Source : Data from HRD PT. Andalan Mitra Prestasi

The table above explains that in the last five years of a total 70 employees of PT. Andalan Mitra Prestasi. The clearest indication that can be seen from the low organizational commitment in practice is the high number of employees who resign or leave the organization.

According to (Rejeki and Wulansari, 2015) several factors that can encourage employee organizational commitment are job satisfaction and organizational justice. Another factor that can influence organizational commitment is the organizational climate (Bahrami et al, 2015).

Job satisfaction is an important concept for the organization. A person's dissatisfaction with this his work, which will affect the level of organizational commitment. The role of job satisfaction is for example satisfied when treated and receiving remuneration fair, satisfied with a comfortable organizational climate and satisfied with the promotion given. Organizational justice and organizational climate perceived by employees will create positive feelings in doing work, which in the end make employees satisfied with their job. Job satisfaction felt by employees will be able to encourage employees to be more committed to their organization, because when employees fell more valued and given their welfare, it will be more comfortable to continue to service in a company. This shows that job satisfaction is able to direct organizational justice and organizational climate into a form of organizational commitment. Thus, job satisfaction is a variable that can mediate the relationship between organizational justice, organizational climate and organizational commitment.

According to (Robins and Judge, 2008) job satisfaction is a positive feeling about someone work which is the result of an evaluation of its characteristics. Job satisfaction according to (Luthans, 2011) the main factors that influence job satisfactions are organizational climate, leadership adn teamwork. According to (Hughes, Ginnett and Curphy, 2012) what organizational leaders must do to improve employee satisfaction and reduce resignation is to use organizational justice theory. Based on all these definitions, its can be conclude that job satisfaction is actually closely related to individual emotions and feeling about how well their work provides things that are deemed feasible or not.

Research that has been done has resulted in job satisfaction influencing organizational commitment (Tania and Sutanto, 2013), other studies show that job satisfaction can be influenced by organizational justice (Indrayani and Suandana, 2016). And research (Gaunya, 2016), job satisfaction can also be influenced by organizational climate.

Organizational Justice is a key element in life and maintaining the development of organizations and employees (Lotfi and Pour, 2013). According to (Robbins and Judge, 2008) organizational justice is defined as the overall perception of what is fair in the workplace. According to (Demirel and Yucel, 2013) organizational justice is a combination of employee attitudes for their organization as a result of 
a comparison of the benefits that employees get in their contributions to their own organizations with the benefits obtained by employees of other organizations. According to (Murtaza et al, 2015) defining organizational justice is the employee's perception of fair and equal treatment in the organization. Organizational justice theory also treats employees with the feeling that their psychological needs for justice will be fulfilled bye the organization (Khan, 2018). It can be concluded that, organizational justice is a perception perceived by employees about fair treatment of the organization to employees.

Previous research has found that organizational justice has a positive influence on job satisfaction and organizational commitment, carried out by (Indrayani and Suwandana, 2016), (Rejeki and Wulansari, 2015), Demirel and Yucel (2013), and (Rahman et all, 2015).

Organizational climate is an organizational phenomenon that is very unique and complex. According to (Wirawam, 2007) defines organizational climate as collections and environmental patterns that determine the emergence of motivation and focuses on perceptions that make sense or can be assessed, so that it has a direct influence on the attitude and behavior of members of the organizations. Climate or climate comes from Greek, namely incline, this word does not only give meaning limited to physical things such as temperature or pressure, but also has a psychological meaning that people in the organization describe the organization's internal environment. Dessler (2015), characterizes organizational climate as a wholeh of physical and social facr=tors contained in an organization. Then started by (Simamora, 2011) started that organizational climate is an internal environment or organizational psychology. Organizational climate is an organizational culture condition which if a good work climate can increase employee morale, loyalty and productivity (Gaunya, 2016). It can be concluded that the organizational climate is a condition regarding the characteristics that occur in the work environment that is felt both directly and indirectly and can affect people's behavior and job satisfaction within the organization.

Quality organizational climate perceived by employees will affect employee job satisfaction is high for the company, high job satisfaction from employees will increase employee commitment to the organization.

The study (Elsabahy, Sleem and El-Sayed, 2013) concluded that organizational climate had a significant positive effect on organizational commitment. Research conducted (Gaunya, 2016) organizational climate has a significant positive effect on employee job satisfaction.

\section{RESEARCH METHODS}

The population in this research is all employees at the head office of PT. Andalan Mitra Prestasi Padang is 70 people. The technique of taking the number of samples in this research is to use systematic random sampling, which is a procedure for determining the sample randomly and systematically (Yusuf, 2017). The sample uses Slovin calculations with an inaccuracy rate of 5\%, which is 60 people. This research discusses in the scope of analyzing the effect of two variables $\mathrm{X}$, namely organizational justice and organizational climate, one $\mathrm{Y}$ variable is organizational commitment with job satisfaction as mediating variable $(Z)$. The type of research currently being conducted is descriptive causal research.

Indicators of organizational commitment are : pride in work, a sense of loyalty to the company, conformity of personal and organizational values, work that inspires and concerns the sustainability of the company (Lambert and Hogan, 2008).

Indicators of job satisfaction are rewards, work stress, job characteristics and disposition influences (Yuen et al, 2018O). Three indicators of organizational justice, namely distributive justice, procedural justice, and interactional justice. Organizational climate is measured through four indicators, namely : morale in the organization, facilities and leader support, cohesian and clarity of system objectivity, work challenges, variation, and feedback (Datta and Singh, 2018).

The data analysis technique in this research uses Structural Equation Model (SEM) - Partial Least Square (PLS). According to (Joseph et al, 2014) SEM is a second generation multivariate data analysis method, multivariate data analysis involves the application of statistical methods that simultaneously analyze several variables that represent measurements related to individuals, companies, events, activities, situations, and so forth. 


\section{Results and Discussion}

Validity Test

Convergent validity is said to be high if the value of loading or indicator score above 0.7 (Ghozali, 2014). The result of the outer loading value indicate that some indicators that measure the variable of organizational justice, job satisfaction, and organizational commitment have loading values below 0.6. the outer loading value indicates that there are 13 invalid indicators explained by the table below. Thirteen invalid indicators will be deleted in this research because the outer loading value is less than 0.6 and the AVE score is below 0.5 .

Table 2 Invalid Indicator

\begin{tabular}{|c|c|c|}
\hline Number & Indicators & Outer Loading \\
\hline \multicolumn{3}{|c|}{ Organizational Justice (X1) } \\
\hline 1. & Leadership decisions are not discriminatory & 0.452 \\
\hline 2. & Treatment of respect for employee & 0.393 \\
\hline 3. & Communication of leader's with the same employee & 0.446 \\
\hline 4. & Decisions made fairly & 0.536 \\
\hline \multicolumn{3}{|c|}{ Job Satisfaction $(\mathrm{X} 3)$} \\
\hline 5. & Salary as an encouragement to work & 0.592 \\
\hline 6. & Leadership support for team work & 0.502 \\
\hline 7. & The leader's encouragement to be enthusiastic & 0.546 \\
\hline 8. & The leader looks an ideas and suggestions & 0.427 \\
\hline 9. & The application of a clear work system & 0.534 \\
\hline \multicolumn{3}{|c|}{ Organizational Commitment $(\mathrm{Y})$} \\
\hline 10. & Commitment to maintain value in the organization & 0.135 \\
\hline 11. & Insuring work & 0.091 \\
\hline 12. & Employee responsibility for the company & 0.013 \\
\hline 13. & Work hard for the company & 0.137 \\
\hline
\end{tabular}

Source : Result of Primary Data Processing, 2019

Table 3 First AVE

\begin{tabular}{ll}
\hline \multicolumn{1}{c}{ Variable } & AVE \\
\hline Organizational Justice & 0.389 \\
\hline Organizational Climate & 0.596 \\
\hline Job Satisfaction & 0.397 \\
\hline Organizational Commitment & 0.341 \\
\hline
\end{tabular}

Source : Result of Primary Data Processing, 2019

After the elimination process is obtained the result of all indicators of the variables studied have met the requirements (more than 0.6) and the AVE score of each variable under research has also met the requirements (more than 0.5 ), namely : organizational justice 0.639 , organizational climate 0.596 , job satisfaction 0.600 and organizational commitment 0.680 .

This research also uses discriminant validity which is used to show that the construct or latent variable predicts the size of a construct with other constructs. The comparison value of the root AVE results that each of these values is greater than the correlation between other variables. So it can be concluded that all latent variables have discriminant validity and good convergent validity. Next is the outer loading image after elimination. 


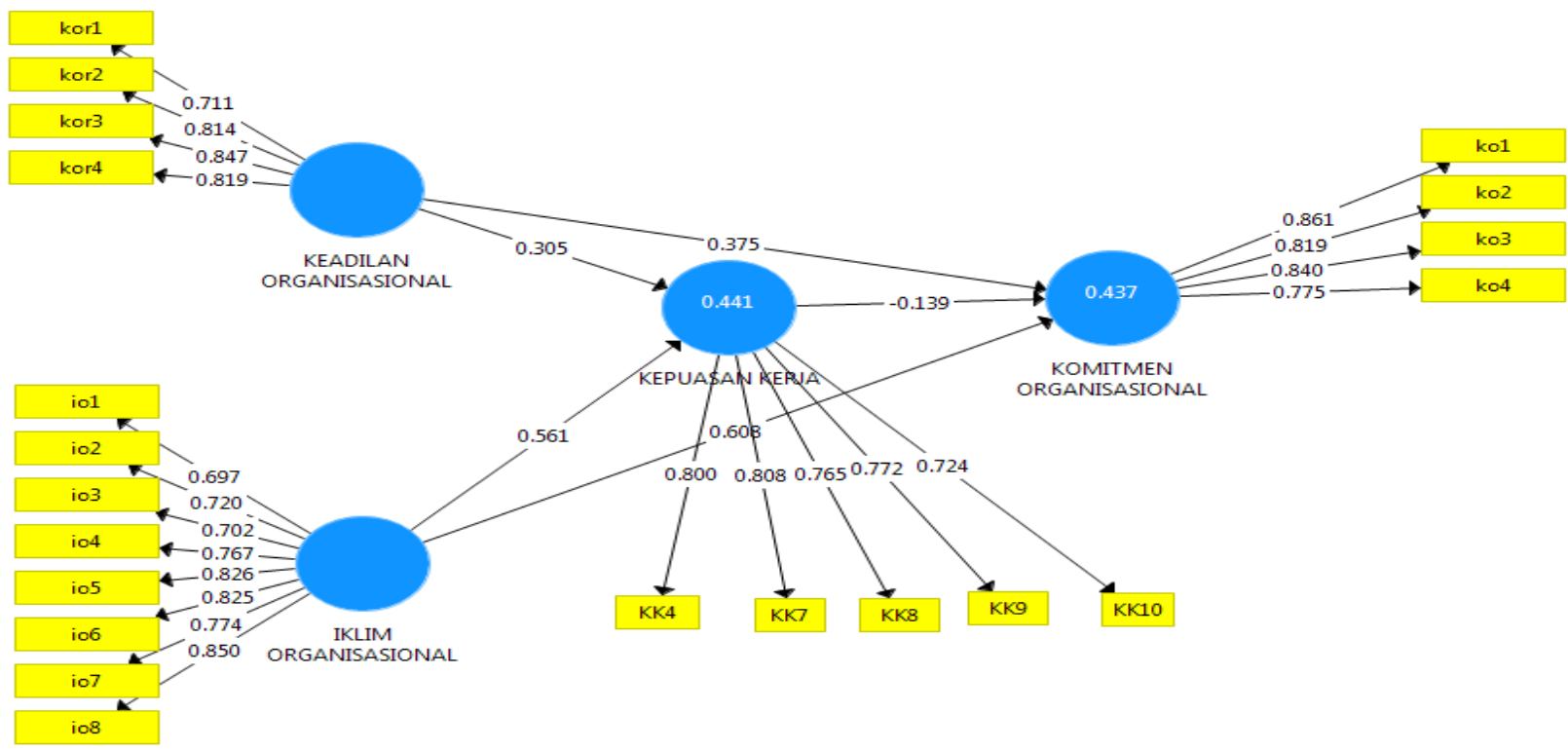

Picture 1 Outer Loading After Modification

Reability Test

It can be explained that the composite reliability value and cronbach alpha of each measured variable has a value greater than 0.6 , so that the indicators used in the research variable can be said to be reliable.

Table 4 Test of Reability of Composite Reliability and Cronbach's Alpha

\begin{tabular}{ccc}
\hline Construct & Composite Reliability & Cronbach's Alpha \\
\hline Justice & 0.876 & 0.815 \\
\hline Climate & 0.9232 & 0.903 \\
\hline Job Satisfaction & 0.882 & 0.840 \\
\hline Commitment & 0.894 & 0.842 \\
\hline
\end{tabular}

Source : Result of Primary Data Processing, 2019

$\mathrm{R}^{2}$ Test

The influence of organizational justice and organizational climate on organizational commitment R-Square value of 0.437 which can be interpreted that the variability of organizational commitment constructs can be explained by the variability of organizational justice constructs and organizational climate by $43.7 \%$ while the rest $(56.3 \%)$ is explained by other variables outside of the research.

The influence of organizational justice and organizational climate on job satisfaction provides an R-Square value of 0.441 which can be interpreted that the variability of organizational justice constructs and organizational climate can be explained by the construct of job satisfaction by $44.1 \%$, while the rest (55.9\%) is explained by other variables other than those studied.

Table 5 R - Square

\begin{tabular}{cc}
\hline Contruct & R-Square \\
\hline KK & 0.441 \\
\hline KO & 0.437 \\
\hline
\end{tabular}

Source : Result of Primary Data Processing, 2019 
Table 6 Hypothesis Testing

\begin{tabular}{lcccc}
\hline & $\begin{array}{c}\text { Original sample } \\
(\mathbf{O})\end{array}$ & $\begin{array}{c}\text { Sample Mean } \\
(\mathbf{M})\end{array}$ & $\begin{array}{c}\text { Standard Deviasi } \\
\text { (STDEV) }\end{array}$ & $\begin{array}{c}\text { T Statistics } \\
\text { (O/STERR) }\end{array}$ \\
\hline $\mathrm{KOR} \rightarrow \mathrm{KK}$ & 0.305 & 0.298 & 0.120 & 2.548 \\
\hline $\mathrm{KOR} \rightarrow \mathrm{KO}$ & 0.375 & 0.386 & 0.118 & 3.190 \\
\hline $\mathrm{IO} \rightarrow \mathrm{KK}$ & 0.561 & 0.570 & 0.095 & 5.918 \\
\hline $\mathrm{IO} \rightarrow \mathrm{KO}$ & 0.608 & 0.630 & 0.115 & 5.277 \\
\hline $\mathrm{KK} \rightarrow \mathrm{KO}$ & -0.139 & $-0,150$ & 0,150 & 0,927 \\
\hline
\end{tabular}

Source : Result of Primary Data Processing, 2019

Based on the hypothesis test ini this study found that organizational justice has a significant positive effect on organizational commitment of PT. Andalan Mitra Prestasi Padang. This means that if employees feel treated fairly by the company, the effect on employee commitment to the company increases. Thus this research provides support for the concept (Hughes, Ginnett and Curphy, 2012), that employees who are treated fairly will be more productive, more satisfied and committed to the organization. In some previous studies, it has been proven that organizational justice has an influence on organizational commitment (Demirel and Yucel, 2013), (Rahman et al, 2016), (Murtaza et al, 2011).

Based on the hypothesis testing carried out the result show that organizational justice has a significant positive effect on job satisfaction of PT. Andalan Mitra Prestasi Padang. That is, the more employees feel fair in the organization, the more their job satisfaction on PT. Andalan Mitra Prestasi will increase. Thus this study provides support for the concept of (Hughes, Ginnett and Curphy, 2012), that what organizational leaders must do to improve employee satisfaction and reduce resignation is to use the theory of organizational justice. These results are supported by previous research that have proven that organizational justice has an influence on job satisfaction (Rezeki and Wulansari, 2015), (Kristanto et al, 2014)

Based on hypothesis testing conducted organizational climate has a positive and significant effect on organizational commitment of employees of PT. Andalan Mitra Prestasi Padang. That is, if the climate perceived by employees in the organization is conducive and comfortable, it will affect employee commitment to the organization. That organizational climate has a significant positive effect on organizational commitment. These results are supported by the results of previous studies conducted by (Elsabahy, et al, 2013)

Based on the hypothesis testing conducted, it was found that organizational climate had a positive and significant effect on job satisfaction of PT. Andalan Mitra Prestasi Padang. This means that a comfortable feeling in the organizational climate felt by employees will affect their increased job satisfaction. That organizational climate has a positive effect on job satisfaction. The results of this research are supported by research conducted (Gaunya, 2016).

The hypothesis testing conducted shows that job satisfaction has a negative and not significant effect on the organizational commitment of PT. Andalan Mitra Prestasi Padang. In some previous research, it has been proven that job satisfaction has an influence on organizational commitment (Indrayani and Suwandana, 2016), (Kristanto, Rahyuda and Riana, 2014). But in the object of this research found the opposite, namely job satisfaction has no significant negative effect on organizational commitment of PT. Andalan Mitra Prestasi Padang.

\section{Conclusions and Recommendations}

Based on the results of the analysis and discussion in the previous chapter, it can be concluded that organizational justice provides a positive and significant effect on organizational commitment of PT. Andalan Mitra Prestasi Padang, organizational justice has a positive and significant effect on job satisfaction of PT. Andalan Mitra Prestasi Padang, national climate gives a positive and significant effect on organizational commitment of PT. Andalan Mitra Prestasi Padang, organizational climate provides a positive and significant effect on job satisfaction of PT. Andalan Mitra Prestasi Padang, job satisfaction provides a negative and not significant effect on organizational commitment of PT. Andalan Mitra Prestasi Padang. 
Based on the results of the research, the most significant value is seen from the parameter coefficient value (original sample). In this research the highest parameter coefficient value is 0.608 , namely the influence of organizational climate on organizational commitment. When viewed from the results of the lowest frequency indicators, it is work spirit in organizations with sub indicators, namely salaries that encourage enthusiasm in work, the average results are 2.93 and the value of Total Respondent Achievement (TCR) is 58.60. That is, the results reflect that the salary they receive as a motivation for work is lacking. The salary that has been given by PT. Andalan Mitra Prestasi Padang, has not been able to increase motivation for employees to be passionate about work. Employees will be eager to work if the company rewards according to their contribution to the company.

Then it is recommended to PT. Andalan Mitra Prestasi Padang to provide performance based rewards. Employees who do higher job performance, low levels of absenteeism and delay, and have good image in running the organization, will get greater rewards because of their achievements. Conversely, employees whose performance is low, often late and not present, receive less rewards than employees who excel. The provision of performance based rewards will certainly make employees feel happy and happy in carrying out their work, thus increasing their commitment to the organization.

\section{References}

Anoraga, Pandji. (2001). Pengantar Pasar Modal Indonesia. Jakarta: Mediasoft Indonesia.

Bahrami, Mohammad Amin, dkk. (2015). Role of Organizational Climate in Organizational Commitment: The Case of Teaching Hospitals. Osong Public Health Res Perspect. 7(2). 96-100

Belias, Dimitrios dkk. (2014). Organizational Culture and Job Satisfaction of Greek Banking Institutions. Procedia - Social and Behavioral Sciences, 175, 314-323.

Datta Amit dan Raghuvir Singh. (2018). Determining the dimensions of organizational climate perceived by the hotel employees. Journal of Hospitality and Tourism Management, 36, 40-48.

Demirel, Yavuz dan İlhami Yücel. (2013). "The Effect of Organizational Justice on Organizational Commitment: A Study on Automotive Industry". International Journal Of Social Sciences, I(3).

Dessler, Gery. (2015). Human Resource Management edisi 14. Jakarta: Penerbit Salemba Empat.

Elsabahy, Hanan Elsaid, Wafaa Fathi Sleem, Neamat Mohamed El-Sayed. (2013). "Effect of Organizatiional Climate On Organizational Commitment Of nurse educator at fculty of nursing mansaura university". Journal of educationand practice, 4(27).

Gaunya, Collins Ruben. (2016). “Organizational Climate as a Determinant of Job Satisfaction among Public Sector Employees in Kisii County, Kenya". Journal of Resources Development and Management, 23, ISSN 2422-8397.

Ghozali, I. (2014). Analisis Multivariate dengan Program SPSS. Semarang: Undip.

Gibson, Ivancevich dan Donnely. (2009). Organizational: Behavior, Structure, Processes. New York: The McGraw Hill Companies, Inc

Hair et al. (2010). Multivariate Data Analysis, Seventh Edition. Pearson Prentice Hall

Hughes, Richard L, et al. (2012). Leadership : Enhancing The Lessons Of Experience. Jakarta: Salemba Hamanika

Indrayani, Luh Putu Cahya dan I Gusti Made Suwandana. (2016). Pengaruh Keadilan Organisasional Terhadap Kepuasan Kerja Dan Komitmen Organisasional Pada Karyawan. E-Jurnal Manajemen Unud, 5(6), 3589-3619

Joseph, et al. (2014). A Primer On Partial Least Square Structural Equation Modeling (PLS-SEM). United States of America: Library of Congress Cataloging-in-Publication Data.

Khan Mavra, Sadia Sarwar, Hiba Khan. (2018). Impact of Corporate Social Responsibility on Job Attitudes: Job Satisfaction and Organizational Commitment of Banking Sector Employees of Pakistan. SEISENSE Journal of Management, 1(3)

Kristanto Sentot, Ketut Rahyuda, dan Gede Riana. (2015). Pengaruh Keadilan Organisasional Terhadap Kepuasan Kerja Dan Dampaknya Terhadap Komitmen, Dan Intensi Keluar Di PT Indonesia Power Ubp Bali". E-Jurnal Ekonomi dan Bisnis Universitas Udayana, 3(6), 308-329 
Lambert, Eric dan Nancy Hogan. (2008). The Importance of Job Satisfaction and Organizational Commitment in Shaping Turnover Intent A Test of a Causal Model. Criminal Justice Review, 34(1), 96-118.

Lotfi, Mohammad Hosein dan Mohammad Shirazi Pour. (2013). The relationship between organizational justice and job satisfaction among the employees of Tehran Payame Noor University. Procedia - Social and Behavioral Sciences, 93, 2073 - 2079.

Luthans, F. (2011). Organizational Behavior, An Evidence Based Approach. Twelve edition, Mc Grow Hill

Murtaza, Ghulam, dkk. (2011). Impact of Distributive and Procedural Justice on Employees' Commitment: A Case of Public Sector Organization of Pakistan. European Journal of Economics, Finance and Administrative Sciences, 29.

Rahman, Asim, dkk. (2016). Effects of Organizational Justice on Organizational Commitment. International Journal of Economics and Financial Issues, 6(S3), 188-196.

Rejeki, Anggraeni Tri dan Nury Ariani Wulansari. (2015). Pengaruh Keadilan Organisasional Pada Komitmen Organsasional Dengan Kepuasan Kerja Sebagai Variabel Intervening. Management Analysis Journal, 4(4).

Robbins dan Judge. (2008). Perilaku Organisasi, Edisi Duabelas. Jakarta: Penerbit Salemba Empat.

Simamora, H. (2011). Manajemen Sumberdaya Manusia Edisi III. Yogyakarta: Bagian Penerbit Sekolah Tinggi Ilmu Ekonomi YKPN.

Tania, Anastasia dan Sutanto, Eddi M. (2013). Pengaruh Motivasi Kerja dan Kepuasan Kerja Terhadap Komitmen Organisasi Karyawan PT. DAI KNIFE Di Surabaya. AGORA,1(3).

Wirawan. (2007). Budaya dan Iklim Organisasi. Salemba Empat : Jakarta

Yuen, Kum Fai. (2018). Determinants of job satisfaction and performance of seafarers". Transportation Research Part A, 110, 1-12

Yusuf, A Muri. (2017). Metode Penelitian. Jakarta: Kencana 